\title{
Corporate Governance When Founders Are Directors
}

\section{Citation}

$\mathrm{Li}$, Feng, and Suraj Srinivasan. "Corporate Governance When Founders Are Directors." Journal of Financial Economics 102, no. 2 (November 2011): 454-469.

\section{Published Version}

10.2139/ssrn.1014157;http://www.sciencedirect.com/science/article/pii/S0304405X11001462

\section{Permanent link}

http://nrs.harvard.edu/urn-3:HUL.InstRepos:29660922

\section{Terms of Use}

This article was downloaded from Harvard University's DASH repository, and is made available under the terms and conditions applicable to Open Access Policy Articles, as set forth at http:// nrs.harvard.edu/urn-3:HUL.InstRepos:dash.current.terms-of-use\#OAP

\section{Share Your Story}

The Harvard community has made this article openly available.

Please share how this access benefits you. Submit a story.

Accessibility 


\title{
Corporate Governance when Founders are Directors
}

\author{
Feng Li \\ Ross School of Business \\ University of Michigan \\ Phone: (734) 936-2771 \\ Fax: (734) 936-0282 \\ Email: Feng@umich.edu \\ Suraj Srinivasan \\ Harvard Business School \\ Phone: (617) 4956993 \\ Fax: (617) 496-7363 \\ Email: ssrinivasan@hbs.edu
}

December 2010

\section{Forthcoming: Journal of Financial Economics}

\begin{abstract}
:
We examine CEO compensation, CEO retention policies, and M\&A decisions in firms where founders serve as a director with a non-founder CEO (founder-director firms). We find that founder-director firms offer a different mix of incentives to their CEOs than other firms. Pay for performance sensitivity for non-founder CEOs in founder-director firms is higher and the level of pay is lower than that of other CEOs. CEO turnover sensitivity to firm performance is also significantly higher in founder-director firms compared to non-founder firms. Overall, the evidence suggests that boards with founderdirectors provide more high powered incentives in the form of pay and retention policies than the average U.S. board. Stock returns around M\&A announcements and board attendance are also higher in founder-director firms compared to non-founder firms.
\end{abstract}

We thank Phil Berger, Aiyesha Dey, Rich Frankel, Joseph Gerakos, Paul Healy, D.J. Nanda, Volkan Muslu, Krishna Palepu, Doug Skinner, Abbie Smith, Eugene Soltes, Bill Schwert (the Editor), Jayanthi Sundar, Jerry Zimmerman, the anonymous referee, and workshop participants at University of Toronto, University of Chicago, Stanford University, Washington University, St. Louis, University of Pittsburgh, the 2008 FARS Mid Year Conference, American Accounting Association meeting and the Indian School of Business Accounting Symposium for useful comments. We thank our respective schools for financial support. The research was funded in part by the Ewing Marion Kauffman Foundation. The views expressed in this paper are the views of the authors and not necessarily the views of the Ewing Marion Kauffman Foundation. Lizzie Gomez, Kei Kondo, and Maxwell Tang provided excellent research assistance. 


\section{Introduction}

We examine corporate governance outcomes when the founder of a company serves as a director on its board by studying three corporate decisions - CEO compensation, CEO turnover, and mergers and acquisitions (M\&A). Almost twenty-five percent of large U.S. companies have their founders actively associated with the company either as the CEO (13\%) or as a member of the board of directors (12\%). We label the former group founder-CEO firms and the latter group founder-director firms. Our focus in this paper is on the role played by founders as directors and not as executives and thus on founder-director companies. ${ }^{1}$ Note that our definition of founder-director firms is mutually exclusive from founder-CEO firms, even though CEOs typically serve on the board of the company. CEOs in founder-director companies are successor CEOs who are not the founder or members of the founder's family.

Prior research posits that founders add value through a combination of specialized knowledge, concentrated and long term ownership, and non-pecuniary (e.g., reputational and emotional) ties to the firm (Demsetz and Lehn, 1985; James, 1999). The greater financial and non-financial ties provide founders with both the ability and the incentives to provide better monitoring when they serve as directors. Founder-directors' greater firm specific experience reduces information problems between the board and managers that may prevent effective oversight (Jensen, 1993). Founder-director companies are therefore likely to have fewer agency problems and be better governed than non-founder companies. Perhaps for this reason, prior studies document that family firms have a higher valuation when founders are actively involved in managing the firm (Andersen

\footnotetext{
${ }^{1}$ Prior papers (e.g., Fahlenbrach, 2009; Adams et al., 2009) have examined the role of founder-CEOs in firm performance and corporate decisions.
} 
and Reeb, 2003; Villalonga and Amit, 2006). Villalonga and Amit (2006, page 404) posits that compared to the value of founders as CEO “founders' skills are almost as valuable when they bring them to the firm through a position as Chairman with a hired CEO in place.” This research motivates our study on the governance role of founders when they become directors of companies they founded.

Our sample consists of 11,686 firm-years of U.S companies between 1996 and 2004 that are covered by Compustat's Execucomp database and Investor Responsibility Research Center's Directors dataset. Similar to prior studies that document a valuation premium in family firms (e.g., Andersen and Reeb, 2003; Villalonga and Amit, 2006), we find that founder-director firms exhibit a valuation premium as measured by Tobin’s Q.

We find that companies with founder-directors behave differently for all of the three decisions that we examine. First, CEOs in founder-director companies have higher pay-for-performance sensitivity (PPS) than CEOs in non-founder firms. For non-founder firms, the average CEO's annual total compensation including the change in value of stock and option holdings increases by about $\$ 5.20$ for a $\$ 1,000$ increase in the market value of the firm. For firms with a founder-director the additional PPS is \$2.24. In addition, after controlling for other economic determinants of pay level, CEOs of founder-director firms receive lower pay than CEOs in non-founder firms. We interpret this as lower excess pay due to better governance in these firms (Core et al., 1999). In terms of economic magnitude, CEOs of founder-director firms, on average, receive $\$ 329,000$ less than CEOs of non-founder firms in annual compensation after controlling for other economic determinants of pay. 
Second, CEOs in founder-director firms are more likely than those in non-founder firms to be replaced for poor performance. A decline in performance from the top to bottom decile in performance increases the likelihood of a forced CEO turnover by almost 8.3\% more in founder-director firms compared to non-founder firms. Lastly, we find that the three-day M\&A announcement return is $1.29 \%$ higher for founder-director firms than other firms.

In addition to examining outcomes related to monitoring and advisory roles of the board, we corroborate our findings using a measure of board effort - director attendance at board meetings (Cai et al., 2009). We find that non-founder directors have a better attendance record in founder-director firms than directors in other firms. This could be because the presence of founder-directors results in better functioning boards or because founder-directors are able to pick more diligent directors for their companies.

Our paper contributes to two major research areas. First, we contribute to the literature on the role of founders in firms. Our results suggest that the founder's role extends to more effective board level monitoring and not just to superior executive performance as documented in prior research. The higher PPS, lower excess compensation, and higher turnover-performance sensitivity are uniquely associated with founder-directors. They are not observed when other directors with firm specific experience (e.g., prior CEOs) serve on the board even when these prior CEOs have high levels of equity ownership in the company. This suggests that the effect reflects more than the founder's expertise and equity incentives to monitor but is likely a combination of these factors and the founder's non-pecuniary attachment in the form of reputational and emotional investment in the firm. 
Our paper complements research cited earlier on family firms that finds that active founders are associated with higher firm value by examining a set of micromechanisms that could drive the association. The evidence of better board decisions that we document makes it more likely that founders have a positive causal effect on firm value and less likely that the association with value documented in prior papers is driven by omitted factors.

Second, our paper adds to research on the role of the board of directors in firm outcomes. To the extent that founder-directors are more willing and able to monitor managers, governance practices in founder-directors firms are closer to first-best. ${ }^{2}$ Our results therefore suggest that compared with the first-best scenarios, the majority of firms (i.e., non founder-director firms) over-compensate managers, provide their CEOs with lower incentive-based pay, and do not replace CEOs in a timely manner when faced with poor performance.

We recognize that we lack a clean instrument to identify the causal effect of founder-directors on firm policy. We control for differences between founder-director and other firms using a large number of observable firm characteristics -firm age, firm size, industry, diversification, accounting and stock return performance, leverage, R\&D and capital expenditure intensity, beta, accounting and stock return volatility, governance features like board size, G-index, board independence, presence of block holders on the board, institutional holdings, board equity ownership, and Delaware incorporation. We also include a number of CEO characteristics as control variables - CEO age, CEO tenure, equity ownership by the CEO, proxies for CEO talent and CEO power, and

\footnotetext{
${ }^{2}$ Fama and Jensen (1983) suggest that managerial control is much simplified in the presence of one or a few concentrated residual claimants with sufficient firm specific knowledge who can ratify and monitor important decisions and set rewards. Founder-directors are a good example of such a residual claimant.
} 
whether the CEO is an internal or external hire. Our results hold after the inclusion of all these controls and present a coherent picture of the structure of CEO incentives in a founder-director company. In robustness tests, we also confirm our results using matched sample tests. Like with all empirical studies lacking clean instruments, we caution against drawing causal inferences from our findings. We cannot rule out the possibility that the associations between the presence of a founder-director and the corporate governance outcomes are due to other unobserved differences in firm or CEO characteristics.

The rest of the paper is organized as follows. Section 2 describes the data and sample. Section 3 presents the empirical evidence, Section 4 presents sensitivity tests and additional analyses, and Section 5 concludes.

\section{Sample and variable definitions}

Our sample of 11,686 companies comprises the intersection of the Investor Responsibility Research Center (IRRC) directors' database and the Execucomp database for the years 1996-2004. We identify founders from biographies of directors in the proxy statement and supplement this using the Forbes 800 list, Business Week (2003) and the Board Analyst database. We also follow Milbourn (2003) and identify the CEO at the founding of the firm as the founder. ${ }^{3}$

Following Milbourn (2003), we identify the CEO as the person who was in office for at least six months of that fiscal year in the years when there is CEO turnover. CEO turnovers are classified as forced or normal using the same method as Parrino (1997). All CEO departures where press reports indicate that the CEO was fired, forced out, or left

\footnotetext{
${ }^{3}$ Founding year data are from the Field-Ritter dataset as used in Field and Karpoff (2002) and Loughran and Ritter (2004) supplemented with incorporation dates collected from Hoovers and Mergent databases.
} 
due to performance problems, policy or other unspecified differences with the board are classified as forced. Departures are recorded as normal if the CEO was aged 60 and above, if the press reports give the reason for departure as death, poor health, acceptance of another position (including board chairmanship), part of a succession plan, due to previously undisclosed personal or business reasons unrelated to the firm's activities, or if the retirement is announced at least 6 months before the departure date. This classification is necessary since boards rarely explicitly dismiss CEOs from their jobs. CEO turnover caused by mergers and spin-offs are excluded from our turnover analysis.

We use the SDC Platinum database to identify all completed acquisitions by sample firms of private, public, and subsidiary targets from January 1992 to December 2005. Following Moeller et al. (2004) we select M\&A deals that satisfy the following criteria: (1) the target firm is a U.S. firm; (2) the deal value is at least \$1million; (3) the percentage stake the acquirer seeks in the deal is at least $50 \%$; and (4) the deal is completed. Firm specific accounting data are from Compustat and stock return data are from CRSP.

\subsection{Variable description and descriptive statistics}

Table 1 Panel A presents the summary statistics on the key variables used in the study. The variable definitions are provided in the Appendix. In our sample, the founders serve as directors with non-founder CEOs $(F D I R=1)$ in roughly 12 percent of the firmyears and in around 13 percent of firm years as the CEO $($ FCEO $=1)$. Eighteen percent of the firm year observations have a former non-founder CEO $\left(P A S T \_C E O=1\right)$ on the board. Like founders, past CEOs have greater firm specific knowledge which can make 
them more effective in monitoring managers than other directors. We also identify past non-founder CEOs with a large equity stake (HI_PASTCEO_HOLD) using a dummy variable that takes the value 1 when the equity stake of the past CEO is larger than the median equity holding of founder-directors in the sample and zero otherwise. The information advantage of the past CEOs combined with a large equity stake provides these directors with the knowledge and financial incentive to monitor managers. We use the non-founder past CEO measures to benchmark the performance of founder-directors. Only about 1 percent of our sample firm-year observations have a founder descendant as the CEO, which is measured by FAM_CEO, an indicator variable coded as 1 if the nonfounder CEO has the same last name as the founder. ${ }^{4}$

The dependent variables used in the study capture features of CEO compensation, CEO turnover, and M\&A decisions. We use two measures of CEO compensation. Annual compensation (ACOMP) is the sum of total annual compensation, including stock options granted. Total compensation (TCOMP) is measured as the sum of the following three components: (i) cash compensation, which is the sum of salary, bonus, and other annual cash payouts over the year; (ii) the Black-Scholes value of options granted and the market value of restricted stock granted during the year and other long-term incentive payouts; and (iii) the change over the year in the market value of equity and options held by the CEO at the beginning of the year. We follow Core and Guay (2002a) in calculating the sensitivity of option portfolio values to stock prices focusing on equity and options held at the beginning of the year to avoid confounding issues related to equity sales and option exercises during the year. The mean (median) ACOMP is $\$ 4.7$

\footnotetext{
${ }^{4}$ We recognize that this methodology misses children and siblings of the founder who may use a different last name but adopt this method for ease of implementation.
} 
million (\$2.5 million) and mean (median) TCOMP is \$15.64 million (\$4.03 million). We observe 1,253 CEO changes, 330 of which we classify as forced and the remaining 923 as normal turnovers. The mean (median) three-day stock returns around the M\&A announcement dates (ARET) is $0.24 \%(0.14 \%)$ and statistically indistinguishable from zero.

Prior studies find that founder firms have different characteristics compared with other firms. ${ }^{5}$ We therefore include the following firm characteristics in the multivariate analysis to control for possible firm-specific differences between founder-director and other firms: firm size (MVE), R\&D intensity ( $R N D)$, leverage ( $L E V)$, firm age (FIRM_AGE), extent of firm diversification (DIVERSIFY), beta (BETA), intensity of capital expenditure (CAPX), extent of option based pay (OPTINT), firm performance measured by stock returns (RET) and accounting return on assets (ROA), return volatility $\left(R E T \_V O L\right)$, and ROA volatility (STD_ROA).

We also include several CEO characteristics as control variables. These are CEO age (CEO_AGE); number of years since appointed CEO (CEO_TENURE); CEO equity ownership (CEO_OWN); CEO reputation as measured by the number of press mentions (MEDIA_MENTIONS) of the CEO in a given year (see Milbourn, 2003), and by the number of other boards that the CEO serves on (OUTSIDE_BD) (see Srinivasan, 2005 and Fich and Shivdasani, 2007); CEO power (CENTRALITY) measured as the ratio of CEO pay to that of the top 5 executives of the firm (see Bebchuk et al., 2009); whether the CEO was promoted internally or was hired from outside (INSIDE_HIRE), (see Parrino, 1997 and Huson et al., 2004).

\footnotetext{
${ }^{5}$ See, for instance, Adams, Almedia and Ferreira (2009), Anderson and Reeb (2003), Anderson, Mansi and Reeb (2003), Anderson and Reeb (2004), Fahlenbrach (2009), Palia and Ravid (2002), Palia, Ravid and Wang (2007), Perez-Gonzalez (2006), Villalonga and Amit (2006), and Villalonga and Amit (2009).
} 
Finally, we include controls for several board characteristics and other governance related variables. $B D \_I N D P$ captures the percentage of independent board members; $B D \_S I Z E$ is the number of directors on the board; INST_HOLD measures the extent of institutional ownership; DIR_HOLD is the average equity ownership by the board of directors; and IND_DIR_BLK identifies block holders among non executive directors on the board (who are not founders). The variable DELAWARE shows that $56 \%$ of our sample firms are incorporated in Delaware. G-INDEX is the governance index from Gompers et al. (2003).

In Table 1 Panel B, we present the descriptive statistics and test results of the differences in the means of the variables by founder status (i.e., non-founder, founderdirector, and founder-CEO firms). The statistical tests use standard errors clustered at the firm level. Consistent with a founder valuation premium, the mean market-to-book ratios of founder-director firms (2.61) and founder-CEO firms (2.38) are higher than for nonfounder firms (1.83). Total compensation (TCOMP) is higher for founder-CEOs (\$29.39 million) than for CEOs in founder-director firms (\$20.51 million) and CEOs of nonfounder firms ( $\$ 12.54$ million) but the annual flow compensation (ACOMP) is similar across the three groups. While higher total compensation for founder-CEOs is consistent with their higher equity ownership in the firms they founded, higher TCOMP for CEOs of founder-director firms compared to other CEOs suggests systematic differences in compensation policy between such firms. The mean percentage of forced CEO turnover $(T N V)$ is $2.69 \%$ for non-founder firms, $5.88 \%$ for founder-director firms, and $2.02 \%$ for founder-CEO firms. The difference in CEO turnover rates between founder-director firms and other firms is statistically significant and suggests differences in CEO retention 
policies. The only statistically significant difference in the M\&A announcement returns (ARET) is between founder-CEO firms (0.81\%) and non-founder firms $(0.12 \%)$. These univariate results suggest that CEO compensation and CEO turnover are different in founder-director firms than in other firms.

Compared to non-founder firms, founder-director firms are more R\&D intensive, less leveraged, younger, more volatile, and more diversified. They have similar market capitalization, higher betas, weaker CEO power as measured by centrality, CEOs serving on fewer boards, older and longer serving CEOs, smaller board size, lower board independence, better shareholder rights protection (G-index), and greater board shareholding.

Compared to founder-CEO firms, founder-director firms are larger in terms of market capitalization, less leveraged, and older. They have older CEOs, CEOs with shorter tenure, larger and less independent boards, lower institutional holdings, and weaker shareholder rights protection. We consider these differences between categories as potential causes of spurious correlation between founder-director status and our outcome measures. Therefore we control for all these variables in our multivariate regressions. ${ }^{6}$

\section{Multivariate results}

\subsection{Founder-directors and value premium.}

Prior studies have documented a valuation premium for family firms where founders are still active (e.g., Andersen and Reeb, 2003; Villalonga and Amit, 2006). We

\footnotetext{
${ }^{6}$ Note that the number of observations in the various multivariate tests is lower than those in the overall sample and vary across the tests due to data availability constraints on the different variables.
} 
use the founder valuation premium finding to motivate that the founder can play a valuable role as a director. We examine the association between founder-director and firm value using the following model for firm $j$ and year $t$ :

$$
\begin{aligned}
Q_{j t}= & \beta_{0}+\beta_{1} \text { FDIR }_{j t}+\gamma \text { Control Variables }_{j t}+\text { industry dummies }_{j}+\text { year dummies }_{t} \\
& + \text { error }_{j t} .
\end{aligned}
$$

The dependent variable is the ratio of the market value of assets to the book value of assets - a proxy for Tobin's Q. Year and industry fixed effects are included in all the regressions. All t-statistics reported in this and later tables are based on standard errors clustered at the firm level to account for within-firm correlations.

The results in Table 2 suggest that the presence of a founder-director is associated with higher value - the coefficient on FDIR is 0.30 (t-statistic $=3.34$ ), implying that Tobin's Q of founder-director firms is 0.30 higher than that of non-founder firms. This magnitude is economically significant compared with the standard deviation and the inter-quartile range of $M T B$ (1.87 and 1.01, respectively from Table 1). This finding is similar to the result in Villalonga and Amit (2006) that family firms among the Fortune 500 companies have higher valuations when the founder is the Chairman with a hired CEO.

However, we find an insignificant coefficient on the founder-CEO variable, which differs from findings of Andersen and Reeb (2003) and Villalonga and Amit (2006), who document a positive relationship between the presence of founder-CEOs and firm valuation. We replicate the analyses in Andersen and Reeb (2003) using our sample and find a positive valuation effect of FCEO similar to the results in Andersen and Reeb (2003) after including the same control variables used in that paper. However, the 
inclusion of a larger set of control variables in our analysis appears to reduce the FCEO coefficient to effectively zero (-0.04 with a t-statistic of -0.37 in Table 2$)$. This result suggests a need to rethink the founder-CEO valuation premium documented in prior literature because a more comprehensive set of control variables explains away the positive relation between founder-CEOs and firm valuation.

Notably, we find that the presence of a former CEO on the board is not statistically associated with firm valuation. The sum of the coefficients on PAST_CEO (0.02) and HI_PAST_CEO_HOLD (-0.09) is negative and significantly lower than the coefficient on FDIR (0.30). The difference is statistically significant (p-value $=0.00$ ). The effect of FDIR on Tobin's Q is greater than that of a past CEO with high equity stake on the board suggesting that the founder director effect is not merely due to the founder directors' expertise and equity driven incentives to monitor but due to a combination of these factors and likely the founders' intrinsic motivation due to non-pecuniary attachment to the firm.

Finally, consistent with Villalonga and Amit (2006), we find that FAM_CEO is negatively related to firm value (coefficient $=-0.40$ and t-statistic $=-2.53$ ). This suggests a lower valuation for firms with a successor CEO from the founder's family. This result is also consistent with the conclusions in Perez-Gonzalez (2006) on the value destroying effects of family-heirs as CEO. Our findings are also related to the evidence in Fahlenbrach (2009) and Adams et al. (2009). These papers do not distinguish between founder-director and founder-CEO firms and find results consistent with our unreported findings active founders (FDIR $+F C E O)$ have a positive association with firm value. 
To understand some channels that might drive the positive association between founder-directors and firm value, we next examine CEO compensation, CEO turnover, and M\&A decisions of founder-director firms to see whether and how these decisions differ compared to non-founder firms.

\subsection{Executive compensation in founder-director firms}

\subsubsection{CEO pay for performance sensitivity}

A priori, it is not clear whether founder-director firms would provide lower or higher sensitivity of pay to performance than other firms. High-powered incentives are useful to motivate managers to take unobservable actions that maximize profits. Since founders have greater firm specific experience than the average director, they are better placed to observe and evaluate managerial actions rather than rely on outcomes. If so, PPS in founder-director firms may be less than in other firms. However, high-powered compensation contracts can also provide managers with incentives to falsify performance, especially if the chances of detection are low (Shleifer and Vishny, 1997; Bergstresser and Philippon, 2006). Recent theoretical papers (Goldman and Slezak, 2006; Crocker and Slemrod, 2009) imply that boards will grant greater equity-based compensation when it is easier to prevent or detect such manipulation. If founderdirectors provide better monitoring, PPS will be higher for CEOs in founder-director firms than for CEOs in non-founder firms. ${ }^{7}$

\footnotetext{
${ }^{7}$ Some preliminary evidence suggests that CEO pay is different in family firms. Andersen and Reeb (2003) present summary statistics that indicate that CEOs in family firms (including family and non-family CEOs) earn nearly $10 \%$ less of their total pay in equity based pay compared to CEOs in non family firms. For comprehensive reviews of the literature related to CEO PPS, please see Murphy (1999) and Frydman and Jenter (2010).
} 
We examine pay-for-performance sensitivity (PPS) using the following empirical specification:

$$
\begin{aligned}
\text { TCOMP }_{j t}= & \beta_{0}+\beta_{1} \text { FDIR }_{j t}+\beta_{2} \mathrm{DMKTVAL}_{j t}+\beta_{3} \mathrm{DMKTVAL}_{j t} * \mathrm{FDIR}_{j t}+\beta_{4} \mathrm{DMKTVAL}_{j t} * \\
& \text { Control Variables }_{j t}+\text { industry dummies }_{j}+\text { year dummies }_{t}+\text { error }_{j t .}
\end{aligned}
$$

In equation (2) above, $\beta 2$ is the pay-for-performance sensitivity i.e., the change in the CEO’s firm-related wealth (TCOMP) for a unit change in firm value (Jensen and Murphy, 1990; Hall and Leibman, 1998).

As in the previous test, we include a number of variables to control for possible differences between founder-director and other firms. In particular, we include variables that prior research has found to influence PPS such as CEO age (Gibbons and Murphy, 1992), firm size (Baker and Hall, 2000; Core and Guay, 2001), and the variance in shareholder dollar returns (Aggarwal and Samwick, 1999a). Prior papers (Hall and Leibman, 1998; Aggarwal and Samwick; 1999a and 1999b; among others) caution that PPS estimation will be influenced by outliers since some CEOs own large portions of the firm's stock (for example Bill Gates of Microsoft). Following these studies, we estimate equation (2) using the median regression technique. The median is less influenced by large outliers and is a more robust estimate of central tendency than the mean. In untabulated sensitivity tests, we re-estimate the regression using OLS (after winsorizing at the $1 \%$ and $99 \%$ level) and using the robust regression procedure described in Hall and Leibman (1998). These robustness checks yield inferences similar to those reported based on median regressions.

Table 3 reports the estimation of equation (2). All the coefficients in the regression are multiplied by 1,000 for ease of interpretation. The coefficient on 
DMKTVAL (the change in the market value of equity) represents the change in CEO wealth for a $\$ 1,000$ change in the market value of the firm. The estimates in Table 3 show that firms with a founder-director have a higher PPS, as indicated by the positive and statistically significant coefficient on FDIR*DMKTVAL. The coefficient shows that the CEOs in firms with a founder-director have an additional change in wealth of \$2.24 for a change in shareholder wealth of $\$ 1,000$. To provide a benchmark for the economic significance of the results, we find that the average PPS for CEOs of non-founder firms in our sample is 5.20, i.e., the CEOs annual total compensation increases (decreases) by about $\$ 5.20$ for a $\$ 1,000$ increase (decrease) in the market value of the firm. Therefore, the \$2.24 incremental difference for founder-director firms is economically significant. Both founder-CEOs (FCEO) and founder descendant CEOs (FAM_CEO) have higher PPS than CEOs in non-founder firms. The coefficient on FCEO * DMKTVAL is 3.47 and that on FAM_CEO * DMKTVAL is 5.44 and both are statistically significant. This is likely the result of a founder-CEO and descendant-CEOs having greater equity holdings in a firm than the average CEO. ${ }^{8}$

We control for a number of mechanisms that can substitute for a founder-director. Notably, the FDIR effect is markedly different from that of having a past CEO with significant shareholdings on the board. The coefficient on FDIR * DMKTVAL (2.24) is larger than the sum of those on PAST_CEO * DMKTVAL $(-0.20)$ and HI_PAST_CEO_HOLD *DMKTVAL (0.12) and the difference is statistically significant (p-value $<0.01$ ). This result shows that having a former CEO with high equity stake on

\footnotetext{
${ }^{8}$ In the main specifications we control for $C E O \_O W N$, measured as the proportion of the firm's equity held by the CEO to make this estimation consistent with all the other tables. However, since CEO_OWN can be mechanically correlated with PPS, we also estimate the same equation without CEO_OWN. There is no change in the inferences when CEO_OWN is removed.
} 
the board is not associated with a similar increase in PPS for the current CEO as having a founder as a director. We also control for the extent of director shareholdings (DIR_HOLD) in the company and the presence of an independent director block holder $\left(I N D \_D I R \_B L K\right)$. The impact of the founder-director is incremental to the impact of equity holding by the board of directors and the presence of a block holder on the board. ${ }^{9}$

\subsubsection{Level of CEO pay}

Next, we examine the relationship between the level of CEO pay and founder status of the firm using the following empirical specification:

$$
\begin{gathered}
\log \left(\text { ACOMP }_{j t}=\beta_{0}+\beta_{1} \text { FDIR }_{j t}+\beta_{2} \text { Control Variables }_{j t}+\text { industry dummies }_{j}+\right.\text { year } \\
\text { dummies }_{t}+\text { error }_{j t}
\end{gathered}
$$

The dependent variable is the logarithm of annual compensation (ACOMP), the amount of total cash compensation plus the fair value of stocks and options granted to the CEO in a fiscal year. This is measured using the variable TDC1 in the ExecuComp database. We control for the economic determinants of pay following Core et al. (1999). After controlling for the economic determinants of pay, a negative coefficient on FDIR is interpreted as lower excess CEO compensation in founder-director firms. As in the previous tests, we include a number of variables to control for the differences between founder-director and other firms.

\footnotetext{
${ }^{9}$ Among the control variables, we note that the coefficient on stock return volatility is positive and significant suggesting higher PPS in companies with greater return volatility. This result differs from findings in papers such as Aggarwal and Samwick (1999), Jin (2002) and Garvey and Milbourn (2003) who find a negative relationship between uncertainty and PPS. However, the Prendergast (2002) survey concludes that the evidence is mixed and shows that a principal's objective of providing incentives to the agent to use superior local information leads to the prediction that incentive strength can increase with risk. Core and Guay (1999), Oyer and Shaefer (2001) and Core and Guay (2002b) evidence is consistent with such prediction.
} 
The results in Table 4 indicate that CEOs in founder-director firms receive lower annual compensation than CEOs in non-founder firms as indicated by the negative and significant coefficient on FDIR (coefficient $=-0.07$, t-statistic $=-2.98$ ). In terms of economic magnitude, for a representative firm with CEO compensation held at the mean level of our sample, switching from a non-founder firm to a founder-director firm implies a reduction in CEO annual pay of about $\$ 329,000$. Note that the mean level of annual compensation (ACOMP) for all firms in our sample is about $\$ 4.7$ million. The economic magnitude of the coefficient on FDIR (-0.07) is smaller than that for former CEO directors with high equity stakes (captured by the sum of coefficients on PAST_CEO (0.07) and HI_PAST_CEO_HOLD (-0.07)) and the difference is weakly statistically significant $(\mathrm{p}$-value $=0.10)$. This suggests that the downward pressure on compensation is even stronger in firms that have a past CEO with high equity stake on the board. ${ }^{10}$

Overall, we find that there is a significant statistical and economic association between CEO PPS and the level of CEO pay and the presence of the founder on the board. CEOs in founder-director firms receive compensation that is more sensitive to firm performance and their excess pay (measured as the deviation from the level determined by economic determinants) is lower.

\subsection{CEO turnover performance sensitivity}

We expect boards with founders to make more timely CEO replacement decisions when faced with deteriorating firm performance since founder-directors have a greater

\footnotetext{
${ }^{10}$ One conjecture about this result is that when former CEOs are on the board, the current CEO tends to have weaker bargaining power and hence lower pay (Evans et al., 2010) We attempt to control for this effect by including variables for the age and tenure of the CEO but we cannot rule out this explanation.
} 
ability and willingness to monitor senior management. We examine CEO turnover performance sensitivity using the following logit regression:

$$
\begin{aligned}
\operatorname{PROB}\left(T N V_{j t}\right)= & \beta_{0}+\beta_{1} * R E T_{j t}+\beta_{2} * R O A_{j t}+\beta_{3} * F D I R_{j t}+\beta_{4} * R E T_{j t} * F D I R_{j t}+ \\
& \beta_{5} * R O A_{j t} * F D I R_{j t}+\gamma * \text { Control Variables }_{j t}+\text { industry dummies }_{j}+ \\
& \text { year dummies } \text { dum }
\end{aligned}
$$

$T N V$ is a dummy variable that equals one if there is a forced CEO turnover in a given year. RET is the industry-adjusted stock returns in the twelve months preceding the turnover date for companies with CEO turnover and $R O A$ is the return on assets calculated as the current year ROA if the turnover occurs between July and December; it is calculated as the previous fiscal year ROA if the turnover happens between January and June following the timing convention in Parrino (1997). ${ }^{11}$ Industry adjustment is done at the two-digit SIC level. We control for the same factors discussed earlier. We include controls for several board characteristics, because prior studies find that the turnover performance sensitivity increases when there are more outsiders on the board (Weisbach, 1988) and decreases with greater presence of busy directors on the board (Fich and Shivdasani, 2006) and with larger board size (Faleye 2003).

Table 5 presents the marginal effects and Z-statistics calculated following Norton, Wang, and Ai (2004) of the logit regression in equation (3). We include ROA and its interactions with the other variables in the regressions, but do not report them in the tables to keep the presentation manageable. The marginal effect of FDIR * RET is negative and significant (-0.057 with a t-statistic of -2.67) showing that CEOs of firms with poor performance are more likely to be replaced when founders are on the board.

\footnotetext{
${ }^{11}$ A large body of prior research provides evidence that CEO turnover is inversely related to firm performance (e.g., Weisbach, 1988; Fee and Hadlock, 2003). See Brickley (2003) for a concise review.
} 
Unreported results show that the interaction of $R O A$ with FDIR is not significant. The marginal effect of $F C E O * R E T$ is negative but statistically insignificant.

To gauge the economic magnitude of the FDIR effect, we conduct the following calculation: when a firm's industry-adjusted return shifts from the $95^{\text {th }}$ percentile $(0.80)$

to the $5^{\text {th }}$ percentile $(-0.65)$, a change of 1.45 , the increase in the probability of a forced CEO turnover is higher by $8.3 \%$ (calculated as $-5.75 \% * 1.45$, where $-5.75 \%$ is the marginal effect of $F D I R * R E T$ ) if the founder is on the board compared with a nonfounder firm. This magnitude is economically substantial, as the average forced CEO turnover rate in our sample is $3.1 \%$. The marginal effect of FDIR*RET $(-0.057)$ is significantly lower than the effect for non-founder former CEOs with large equity stakes captured by the sum of the coefficients on PAST_CEO*RET (-0.001) and HI_PAST_CEO_HOLD*RET (-0.001). This shows that boards with a founder-director are more likely to replace a CEO for poor performance than those with a non-founder past CEO with a high equity stake.

\subsection{Merger and acquisition returns}

Next, we examine if founder-director firms make better M\&A decisions. The board of directors advise CEOs on M\&As and evaluate their strategic decisions (Jensen, 1993). Grinstein and Tolkowsky (2004) find that many boards have explicit committees to review M\&A transactions. If the presence of a founder-director on the board implies better monitoring of the M\&A process, it would be associated with more efficient M\&A decisions and therefore higher announcement returns. 
Our sample firms completed a total of 3,504 acquisitions at an average of 0.3 transactions per year during the sample period; however, the median firm completes zero M\&A transactions. We examine the acquirer market reaction to the acquisition announcement using the following specification:

$$
\begin{aligned}
\text { ARET }_{j t}= & \beta_{0}+\beta_{1} \text { FDIR }_{j t}+\gamma \text { Control Variables }_{j t}+\text { Industry dummies }_{j}+\text { Year } \\
& \text { dummies }_{t}+\text { error }_{j t .},
\end{aligned}
$$

where ARET is the three day $(-1,1)$ announcement returns for the acquirer centered around the deal announcement date. As in earlier tests, we include the full set of variables to control for the difference between founder-director and other firms. In addition, we control for other determinants of announcement returns: PCT_CASH (the percentage of cash to the value of the acquisition); PCT_ACQ (the percentage of the target acquired); DEAL_SIZE (the size of the transaction); the size of the deal relative to the acquirer (REL_SIZE); and whether the deal is diversifying or not (DIV_MERGER) following prior studies (Asquith et al., 1983; Fuller et al., 2002; Betton et al., 2008). The data requirement for all the control variables leads to a final sample of 1,734 acquisitions completed by our sample firms.

The results in Table 6 show that acquirer returns during the announcement window for founder-CEO firms are 1.99\% higher than that for non-founder firms (tstatistic $=2.71)$ and the announcement returns for founder-director firms are $1.29 \%$ higher than for non-founder firms $(\mathrm{t}$-statistic $=2.11)$. This suggests that founder-director firms, on average, make better merger and acquisition decisions than non-founder firms. Note that while the coefficient on FDIR (1.29) is larger than the sum of those on 
PAST_CEO (0.30) and HI_PAST_CEO_HOLD (-0.07) the difference is not statistically significant.

Prior studies suggest that certain M\&A deal characteristics (e.g., diversification) might suggest value-destroying mergers and managers’ empire building incentives (see Betton et al., 2008 for a comprehensive review). We therefore examine if the presence of a founder-director is associated with the following deal characteristics: the frequency of M\&A deals, diversifying transactions, deal size, acquisition premium, and the percentage of cash used in the acquisition. In untabulated results, we find no significant coefficient on FDIR as a determinant of these deal characteristics (i.e., when the deal characteristics are the dependent variables and our complete set of control variables in Table 6 are included). This shows that while founder-director firms tend to make better acquisitions on average there are no observable differences in the deal characteristics of founderdirector firms compared to those of other firms.

A caveat to using announcement returns to measure M\&A efficiency is that this approach assumes that there is no systematic difference between founder-director and other firms in the extent of pre-announcement leakage of information about impending acquisitions. ${ }^{12}$ In unreported tests, we examine whether this assumption is valid. The results indicate no systematic difference in the target company stock returns in the 60-day and 30-day run-up periods before the announcement, suggesting that founder-director firms are not less likely to leak the acquisitions to the market before the deals are announced. Therefore, we consider the announcement return a reasonable measure of M\&A efficiency.

\footnotetext{
${ }^{12}$ More generally, the approach assumes that there is no difference in market's expectation of the probability and expected quality of M\&A bids between founder-director and other firms.
} 


\subsection{Board attendance in founder-director firms}

We have documented some important differences in CEO compensation, CEO turnover, and M\&A outcomes between founder-director and non-founder firms. While the above three outcomes are the primary board decisions that we examine, we corroborate our findings using an input measure of board diligence and monitoring effort - attendance at board meetings following Cai et al. (2009). We ask the question - is the presence of a founder on the board associated with a better attendance record at board meetings?

The Securities Exchange Act of 1934 requires that companies list in their proxy statement the names of directors who attended less than 75 percent of the board and committee meetings in the previous fiscal year. We merge the attendance data available in the IRRC directors' database with directors' fee data available in ExecuComp. To our knowledge, Adams and Ferreira (2008) is the only large sample study on determinants of director attendance at board meetings. Using data between 1996 and 2003, they find that directors are less likely to have attendance problems at board meetings (i.e., fewer directors attend less than 75\% of all board meetings) when board meeting fees are higher.

We conduct the analysis at the firm-year level. ${ }^{13}$ Attendance problem at the director level is a dummy variable that equals 1 if a director attended fewer than $75 \%$ of the meetings during that year and is 0 otherwise. The dependent variable ATTENDANCE is the average attendance problem of all the non-founder directors. We measure attendance only for non-founder directors since founders may be more committed to

\footnotetext{
${ }^{13}$ We also conduct the analysis at the individual director level in unreported tests - our inferences remain unchanged from those reported for the firm level tests.
} 
attending board meetings and we want to exclude this effect in the dependent variable. As in the earlier tests, we include the full set of variables to control for the differences between founder-director and other firms. In addition, following Adams and Ferreira (2008), we control for the following additional variables that are possible determinants of directors' attendance: fees that directors receive for attending meetings (DIR_MTG_FEE); the average number of years the firm's directors have served on the board (DIR_TENURE); average number of director positions held by the firms directors in other firms (OTHERPOS); average of non-founder director compensation excluding meeting fees $\left(D I R \_C O M P\right)$ and the mean of the retirement status of non-founder directors (retirement status takes the value 1 if the non-founder director is classified as retired from primary executive responsibilities by the IRRC database) (RETIRED). Data requirements shrink our sample size to 3820 firm-years.

Table 7 presents the results from the following firm-year level regressions: Attendance $_{j t}=\beta_{0}+\beta_{1}$ FDIR $_{j t}+\gamma$ Control Variables $j \mathrm{jt}$ Industry dummies I $_{j}+$ Year

$$
\text { dummies }_{t}+\text { error }_{j t} \text {. }
$$

The results show that presence of a founder-director is associated with improved attendance - the coefficient on FDIR is $-0.02(\mathrm{t}$-statistic $=-4.82)$ i.e., the attendance problem is lower in founder-director firms. Interestingly, we do not find a similar relationship for founder-CEO firms (coefficient on $F C E O=0.01$; t-statistic $=1.51$ ). The coefficient on FDIR (-0.02) is more negative than the sum of those on PAST_CEO (-0.00) and HI_PAST_CEO_HOLD $(0.00)$ and the difference is statistically significant. This result indicates that directors have a better attendance record in founder-director companies than in those with a former CEO with high equity stake on the board. 
The evidence of a positive association between the presence of a founder-director and the attendance frequency of other directors in the firm can be interpreted in two ways. First, it may be the case that the founders' presence creates a better functioning board and encourages greater attendance. Alternately, founder directors may be better at picking more diligent directors to serve on the board.

\section{Sensitivity tests and additional analysis}

\section{1 Non-linear relationships}

We examine whether the results are sensitive to the functional form of our regression equations. We use log of market value as a proxy for firm size because of the inherent skewness in the distribution of firm size. We relax the log linear relationship for firm size in the PPS test and include untransformed market value as the measure of firm size. There is no difference in our inferences. We also experiment with other modifications to test for sensitivity to functional form. For instance, we included squared terms for some of the key independent variables - firm size and firm age. The results are invariant to this change.

We also conduct matched sample tests for all the regressions in the paper. We identify firm age and firm size as two of the most critical variables that identify founderdirector firms. Younger and smaller firms are more likely to have founders still active in the firm. For every firm that has a founder-director, we find a matching firm without a founder-director or founder-CEO with the same firm age and the closest market value of equity. We find matches for 1,708 founder-director firms. Untabulated results based on the matched sample confirm the cross sectional results for PPS, level of pay, CEO 
turnover, and attendance tests. The magnitude of the coefficients on FDIR and its interactions are comparable to those that we present in the main cross sectional tables. The coefficient estimate on FDIR is statistically significant only at one-sided level (two sided $\mathrm{p}$-value $=0.18$ ) in the M\&A announcement return test even though the sign and magnitude are similar to that in Table 6 (coefficient $=1.12$, t-stat $=1.35$, $\mathrm{p}$-value $=0.18)$. However, the power of the test is low with only 522 observations in the matched sample.

\subsection{Industry and year fixed effects interactions}

While we control for industry and year dummies in all the regressions, it is possible that there are industry-year specific differences that are not correctly taken into account. To account for this, we include a full set of industry-year fixed effects, i.e., the interaction of industry and year fixed effects. Although this empirical specification is not used widely in the literature, it provides an extremely strong test of the hypotheses by exploring the variations within an industry in a given year. We are unable to implement this specification in the median regression in the PPS tests because the median regression does not converge in the presence of the large set of interaction terms. Instead we implement an OLS version of this regression. All results are robust to the inclusion of industry-year interaction dummies.

\subsection{Industry effects in CEO turnover}

Our primary tests use industry-adjusted stock returns as the measure of firm performance. Jenter and Kanaan (2008) suggest that industry performance might not be fully removed from CEO turnover decisions. We therefore include industry performance 
and its interaction with FDIR as additional independent variables with same control variables as in the main tests in Table 5. Unreported results show that the main inferences on the interaction between FDIR and stock return performance (FDIR * RET) continue to be supported in this analysis. The interaction of FDIR with industry level returns is not statistically significant $(\mathrm{p}$-value $=0.598)$.

\subsection{Percentage and dollar amount of the equity stake of founder-director}

The relatively large equity ownership of a founder-director may provide economic incentives to monitor management and the control rights to effectively conduct the monitoring. A director's incentive to monitor should be determined by the dollar value of her equity holdings, while her control rights should be determined by her percentage stake in the firm. We assess whether the implications of founder director for corporate governance are due to their higher equity incentives or greater control rights.

We calculate the percentage of equity ownership a founder-director has (FPCT) and the absolute dollar value of the holdings using the market value of the equity at the end of prior fiscal year (FDOLLAR). We then reexamine the compensation and CEO turnover decisions by including FDIR with $\log (F P C T)$ or $\log (F D O L L A R)$ in the regression. Unreported results indicate that after controlling for FDOLLAR or FPCT, FDIR is still associated with higher PPS, lower level of CEO pay, and more frequent CEO turnover when firm performance is poor. Both FDOLLAR and FPCT are statistically significant, but their effects are smaller compared with FDIR. ${ }^{14}$ Overall, the

\footnotetext{
${ }^{14}$ We do not include both FDIR and FPCT in the regression together to avoid serious multicollinearity problems since these two variables are highly correlated (Pearson correlation coefficient 0.93 ).
} 
evidence suggests that founder-directors have implications for corporate governance through mechanisms beyond equity incentives and greater control rights.

\section{Conclusions}

We examine firm value and corporate governance outcomes relating to CEO compensation, CEO turnover, and mergers and acquisitions when the founder of a company serves as a director on its board with a non-founder successor as the CEO. We find that the presence of founder-directors is associated with higher firm value as measured by Tobin's Q. This confirms related results in prior literature on the positive association between the presence of founders in family firms and firm value.

Our evidence suggests that firms with a founder-director tend to have higher CEO pay-performance sensitivity, lower excess compensation in the level of pay, and higher CEO turnover-performance sensitivity. This suggests greater alignment of CEO incentives with shareholders interests through high-powered incentives. We also find higher announcement returns for M\&A transactions announced by founder-director firms compared to those of non-founder firms. We corroborate the findings of better board governance using board meeting attendance a measure of greater board effort. We document better attendance at board meetings by non-founder directors when firms have a founder on the board. These results are unique to the presence of founder-directors and are not observed when the board has a past CEO with a high equity stake. This indicates that the founder's non-pecuniary attachment to the firm through emotional ties and reputational investment plays a role in board decisions beyond firm specific knowledge and equity holding that the past CEOs with high equity stakes also possess. 
The evidence collectively shows that the presence of founders on the board is associated with better board decisions, greater diligence, and effective monitoring on the part of corporate boards. To the extent that founder-director firms are better governed and experience fewer agency problems, these results suggest that other firms on average would provide more high powered incentives (both compensation and retention) and lower pay to their CEOs if agency costs were reduced through better governance.

Finally, these results suggest a channel which can drive the observed association between the presence of founders and higher firm valuation. The evidence of better board decisions that we document makes it more likely that founders have a positive effect on firm value and less likely that the association with value documented in prior papers is driven by omitted factors. 


\section{References}

Adams, R. B.; H. Almeida; and D. Ferreira. "Understanding the Relationship between FounderCEOs and Firm Performance.” Journal of Empirical Finance, 16 (2009), 136-150.

Adams, R.B., Ferreira, D., 2008. Do directors perform for pay?. Journal of Accounting and Economics 46, 154-171.

Aggarwal, Rajesh K., and Andrew A. Samwick, 1999a, "The other side of the trade-off: The impact of risk on executive compensation.” Journal of Political Economy 107, 65-105.

Aggarwal, Rajesh K., and Andrew A. Samwick, 1999b, "Executive compensation, strategic competition, and relative performance evaluation: Theory and evidence.” Journal of Finance 54, 1999-2043.

Ai, C., Norton, E., 2003. Interaction terms in logit and probit models. Economic Letters 80, 123129.

Anderson, Ronald and David M. Reeb, 2003, "Founding family ownership and firm performance: Evidence from the S\&P 500.” Journal of Finance 58, 1301-1329.

Asquith, P., R. F. Bruner, D. W. Mullins. 1983. The gains to bidding firms from merger. $J$. Financial Economics. 11 121-139.

Baker, George P., and Brian J. Hall, 2000, “CEO incentives and firm size.” Working paper no. 6868, National Bureau of Economic Research.

Bebchuk, Lucian, Jesse Fried and David Walker, 2002, "Managerial Power and Rent Extraction in the Design of Executive Compensation,” University of Chicago Law Review 69, 751-846.

Betton, Sandra, B. Espen Eckbo, and Karin S. Thorburn, 2008, “Corporate Takeovers”, Handbook of Corporate Finance: Empirical Corporate Finance: Elsevier/North-Holland

Bergstresser, D., and T. Philippon. "CEO Incentives and Earnings Management." Journal of Financial Economics 80 (2006): 511-29.

Brickley, James A., "Empirical research on CEO turnover and firm-performance: A discussion." Journal of Accounting and Economics 36 (2003), pp. 227-233.

Bushman, Robert M., Dai, Zhonglan and Wang, Xue, "Risk and CEO Turnover", Journal of Financial Economics, Volume 96, Issue 3, June 2010, Pages 381-398

Cai, J., Garner, J.L., Walkling, R.A., 2009. Electing directors. Journal of Finance 64 (5), 23892421.

Core, John and Wayne Guay, 1999, The Use of Equity Grants to Manage Optimal Equity Incentive Levels, Journal of Accounting and Economics 28: 151-184.

Core, John, and Wayne Guay, 2001, "The other side of the tradeoff - A comment.” Working paper, Wharton School, University of Pennsylvania. 
Core, John and Wayne Guay, 2002a. Estimating the value of employee stock option portfolios and their sensitivities to price and volatility. Journal of Accounting Research. 40 (2002): 613-630.

Core, John E. and Guay, Wayne R., 2002b, The Other Side of the Trade-Off: The Impact of Risk on Executive Compensation: A Revised Comment (November 2002). Available at SSRN: http://ssrn.com/abstract=292955 or doi:10.2139/ssrn.292955

Core, John E. Robert W. Holthausen, David F. Larcker, 1999, “Corporate governance, chief executive officer compensation, and firm performance.” Journal of Financial Economics, 51, 371-406.

Crocker, K. J., and J. Slemrod, 2007, The Economics of Earnings Manipulation and Managerial Compensation, Rand Journal of Economics 38, no. 3: 698-713.

Demsetz, Harold, and Lehn, Kenneth. "The Structure of Corporate Ownership: Causes and Consequences.” Journal of Political Economy 93 (December 1985): 1155-1177.

Fahlenbrach, R., "Founder-CEOs, Investment Decisions, and Stock Market Performance," Journal of Financial and Quantitative Analysis. Vol. 44, No. 2, Apr. 2009, pp. 439-466

Faleye, Olubunmi, 2003, "Does One Hat Fit All? The Case of Corporate Leadership Structure." Available at SSRN: http://ssrn.com/abstract=394980

Fama, Eugene F. and Jensen, Michael C., "Agency Problems and Residual Claims". 1983, Journal of Law \& Economics, Vol. 26, June 1983

Fee C.E., and C.J. Hadlock, 2003, "Raids, rewards, and reputations in the market for managerial talent.” Review of Financial Studies 16 (4), pp. 1315-1357.

Fich, Eliezer M. and Anil Shivadasani, 2006, “Are Busy Boards Effective Monitors?” The Journal of Finance 61 (2), 689-724.

Field, Laura C. and Jonathan Karpoff, 2002, "Takeover Defenses of IPO Firms." Journal of Finance Vol. 57. No. 5, pp. 1857-1889,

Frydman, Carola and Jenter, Dirk, CEO Compensation (March 19, 2010). Rock Center for Corporate Governance at Stanford University Working Paper No. 77. Available at SSRN: http://ssrn.com/abstract=1582232

Fuller, K., J. Netter, M. Stegemoller. 2002. What do returns to acquiring firms tell us: Evidence from firms that make many acquisitions. Journal of Finance 57 1763-1793

Garvey, Gerald T. and Todd T. Milbourn, 2003, Incentive Compensation When Executives Can Hedge the Market: Evidence of Relative Performance Evaluation in the Cross Section, The Journal of Finance 58 (4), 1557-1581.

Gibbons, Robert, and Kevin J. Murphy, 1992, “Optimal incentive contracts in the presence of career concerns: Theory and evidence.” Journal of Political Economy 100, 468-505. 
Gompers, Paul A., Joy L. Ishii, and Andrew Metrick, "Corporate Governance and Equity Prices." The Quarterly Journal of Economics 118(1), February 2003, 107-155.

Goldman, E., and S. L. Slezak, 2006, An Equilibrium Model of Incentive Contracts in the Presence of Information Manipulation, Journal of Financial Economics 80, no. 3: 603-26.

Grinstein, Yaniv and Tolkowsky, Efrat, 2004, "The Role of the Board of Directors in the Capital Budgeting Process - Evidence from S\&P 500 Firms” Available at SSRN: http://ssrn.com/abstract=625141

Hall, Brian J. and Leibman, Jeffrey B. 1998, “Are CEOs Really Paid Like Bureaucrats?” Quarterly Journal of Economics, 113(3): 653-691.

Huson, M., Malatesta, P., and Parrino R. "Managerial Succession and Firm Performance."Journal of Financial Economics, Vol. 74 (2004), 237-275.

James, Harvey. 1999, “Owner as Manager, Extended Horizons and the Family Firm.” International Journal of Economics and Business, 6, 41-56.

Jensen, Michael C. 1993. "The modern industrial revolution, exit and the failure of internal control systems.” Journal of Finance 48(3) 831-880.

Jensen, Michael C., KJ Murphy. 1990, "Performance Pay and Top-Management Incentives.” Journal of Political Economy. Vol. 98, No. 2, pp. 225-264.

Jenter, Dirk C. and Kanaan, Fadi, 2008, "CEO Turnover and Relative Performance Evaluation" MIT Sloan Research Paper No. 4594-06 Available at SSRN: http://ssrn.com/abstract=885531

Jin, Li, 2002, CEO Compensation, Diversification, and Incentives, Journal of Financial Economics 66, 29-63.

Lorsch, J. L., and E. M. MacIver. "Pawns or Potentates? The Reality of America's Corporate Boards.” Boston, MA: Harvard Business School Press, 1989.

Loughran, Tim and Jay R. Ritter, 2004, "Why Has IPO Underpricing Changed Over Time?" Financial Management Vol. 33, No. 3, pp. 5-37.

Milbourn, Todd, 2003, “CEO reputation and stock-based compensation” Journal of Financial Economics 68 pp. 233-262

Moeller, Sara B., Frederik P. Schlingemann, and René M. Stulz, 2004, "Firm size and the gains from acquisitions.” Journal of Financial Economics Vol. 73, No. , pp. 201-228.

Murphy, Kevin J., 1999, “Executive Compensation,” in Orley Ashenfelter and David Card (eds.), Handbook of Labor Economics, Vol. 3b, Elsevier Science North Holland, Chapter 38: 2485-2563.

Norton, Edward, Hua Wang, and Chunrong Ai, 2004. Computing interaction effects and standard errors in logit and probit models, Stata Journal 4, 103-116. 
Oyer, Paul, and Shaefer, Scott. "Why Do Some Firms Give Stock Options to All Employees? An Empirical Examination of Alternative Theories." Journal of Financial Economics, 76, April 2005, 99-133

Palia, David, Abraham Ravid. 2002. The Role of Founders in Large Companies: Entrenchment or Valuable Human Capital? Working Paper Rutgers University.

Palia, David, Abraham Ravid and Chia-Jane Wang. Founders Versus Non-Founders in Large Companies: Financial Incentives and the Call for Regulation, Journal of Regulatory Economics, October 2007

Parrino R. 1997. “CEO Turnover and outside succession. A cross-sectional analysis.” Journal of Financial Economics 46, 165-197.

Pérez-González, F., 2006. Inherited control and firm performance. American Economic Review 96, 1559-1588.

Prendergast, Canice, 2002, The Tenuous Trade-Off between Risk and Incentives, Journal of Political Economy 110 (5), 1071-1102.

Shleifer, Andrei and Robert W. Vishny, 1997, "A survey of corporate governance." Journal of Finance 52, 737-83.

Srinivasan, S. 2005. Consequences of financial reporting failure for outside directors: Evidence from accounting restatements. Journal of Accounting Research 43 (May): 291-334.

Villalonga, Belen, and Raphael Amit. 2006, "How Do Family Ownership, Control, and Management Affect Firm Value?" Journal of Financial Economics 80, No. 2 pp. 385-417.

Villalonga, Belen, and Raphael Amit. "How Are U.S. Family Firms Controlled?" Review of Financial Studies 22, no. 8 (2009)

Weisbach, Michael S., 1988, “Outside directors and CEO turnover.” Journal of Financial Economics 20, 431-460. 


\section{Appendix: Variable Definitions}

$\underline{\text { Founder-related variables }}$

FDIR: a dummy variable that equals one if a firm has a founder on its board (but not as the CEO) and zero otherwise

FCEO: a dummy variable that equals one if a firm has a founder as its current CEO and zero otherwise

PAST_CEO: a dummy variable that equals one if a firm has a non-founder past-CEO on its board and zero otherwise

FAM_CEO : a dummy variable that equals one if the current CEO is a member of the founder's family identified if the CEO and founder have the same last name and zero otherwise.

\section{$\underline{\text { Dependent variables }}$}

Tobins' $Q$ (Table 2): the market value of equity plus the book value of total liabilities divided by the book value of assets. This variable is also labeled as MTB for Market-toBook in Table 1.

TCOMP (Table 3): the sum of (i) cash compensation (the sum of salary, bonus, and other annual cash payouts over the year); (ii) the Black-Scholes value of options granted and the market value of restricted stock granted during the year and other long-term incentive payouts; and (iii) the change over the year in the market value of equity and options held by the CEO at the start of the year expressed in millions of dollars. The sensitivity of option portfolio value to stock prices is calculated following Core and Guay (2002a).

ACOMP (Table 4): the sum of (i) cash compensation (the sum of salary, bonus, and other annual cash payouts over the year); and (ii) the Black-Scholes value of options granted and the market value of restricted stock granted during the year and other long-term incentive payouts.

TNV (Table 5): a dummy variable that equals 1 if there is forced CEO change in a given year and 0 otherwise.

ARET (Table 6): M\&A announcement percentage returns, in percentage, in the $(-1,1)$ window around M\&A deal announcement dates.

Attendance (Table 7): the average attendance record of the non-founder directors. The attendance record of an individual director is a dummy variable that equals 1 in a given fiscal year if a director missed more than $25 \%$ of the board meetings, and 0 otherwise.

Independent variables: Firm characteristics

MVE: the market value of equity in \$million.

$R N D$ : the amount of R\&D expenditures divided by the amount of sales.

$L E V$ : the book value of debt divided by the book value of assets. 
FIRM_AGE : the number of years since a firm's founding date.

DIVERSIFY: a dummy variable that equals 1 if a firm has more than one segment reported and 0 otherwise.

CAPX: the ratio of capital expenditure over the book value of assets.

BETA: the beta estimated using the stock returns data from the past 60 months before the end of the fiscal year end date.

$R O A$ : return on assets, calculated as earnings divided by the book value of assets.

$R E T$ : Stock returns net of the 2-digit SIC industry returns.

STD_ROA: the standard deviation of return on assets, estimated using data from the past 3 years.

RET_VOL: the standard deviation of the monthly stock returns in the last 60 months.

DMKTVAL : the change in the market value of equity over the year.

Independent variables: Board characteristics and other governance variables

DIR_HOLD : the average equity ownership of all the board members (in percent).

BD_SIZE: the number of board members.

BD_INDP : the ratio of independent board members.

OPTINT : the amount of stock options granted divided by the total annual compensation (including cash salary, bonus, and stock options grant) of the CEO

INST_HOLD : the institutional ownership of a firm's equity.

G_INDEX : the g-index as calculated in Gompers et al. (2003).

HI_PASTCEO_HOLD: a dummy variable that equals 1 if a director who is a former CEO owns more than the median equity ownership of all the founder-directors in our sample, and 0 otherwise

DELAWARE: a dummy variable that equals 1 if a firm is incorporated in Delaware and 0 otherwise.

IND_DIR_BLK : a dummy variable that equals 1 if a firm has an independent director that is a block holder (i.e., owns more than $5 \%$ of the company's stock) and 0 otherwise.

Independent variables: CEO characteristics

MEDIA_MENTIONS: the number of times that a firm's CEO is mentioned in the press during the fiscal year as reported in the Factiva database. 
CENTRALITY: the ratio of CEO pay to the sum of the pay of the top 5 executives

OUTSIDE_BD: the number of board positions that a CEO holds in other companies in the IRRC database.

CEO_OWN: the percentage of stock ownership in a company by its CEO

TENURE: the number of years a CEO has been in that position

CEO_AGE: the age of the CEO

INSIDE_HIRE: a dummy variable that equals 1 if a CEO is promoted from inside the firm and 0 otherwise. Following Parrino (1997) new CEOs are classified as outsiders if they have been with the firm for one year or less when they are appointed as CEO. Others are classified as insiders.

Additional variables used in the merger and acquisition tests

PCT_CASH: the percentage of cash payment used in the M\&A transaction.

$P C T \_A C Q:$ the percentage of ownership of the target company that is acquired in the M\&A transaction.

$D E A L \_S I Z E$ : the M\&A deal value (in \$ million).

DIV_MERGER: a dummy variable that equals 1 if the target has a different 2-digit SIC industry code than the acquirer, and 0 otherwise.

REL_SIZE: the value of the M\&A transaction scaled by the market value of equity of the acquirer at the end of the prior fiscal year.

\section{$\underline{\text { Additional variables used in the director attendance tests }}$}

DIR_MTG_FEE: the fee directors receive for attending board meetings. Average across all non-founder directors.

DIR_TENURE: the average across of non-founder directors of the number of years since the non-founder director has been a director in a firm.

OTHERPOS: the average of the mean number of director positions a director takes in other firms in the IRRC database for all non-founder directors in a firm.

DIR_COMP: the average total compensation for all the non-founder directors received for the board responsibilities. For each non-founder director, compensation is the sum of the cash annual retainer plus the value of annual share and option grants. Annual option grant value is calculated using Black-Scholes model and input parameters from the ExecuComp database. Annual share grants value equals the amount of stock granted times the price at the close of the fiscal year end. 
RETIRED: the mean of the retirement status for all non founder directors on the board. A directors retirement status is a dummy variable that equals 1 if his/her primary title in the IRRC database contains the string "RETIRE" and 0 otherwise.

STK_HOLD: the average stock holdings, in percentage, of the non-founder directors in the company.

DIR_AGE: the average age of the non-founder directors. 
Table 1 : Summary Statistics

Panel A: Sample descriptive statistics

\begin{tabular}{|c|c|c|c|c|c|c|}
\hline Variable & N.Obs & Mean & Std. Dev. & $p 25$ & $p 50$ & $p 75$ \\
\hline FDIR & 11686 & 0.12 & 0.33 & - & - & - \\
\hline FCEO & 11686 & 0.13 & 0.33 & - & - & - \\
\hline PAST_CEO & 11686 & 0.18 & 0.38 & - & - & - \\
\hline FAM_CEO & 11686 & 0.01 & 0.12 & - & - & - \\
\hline MTB & 11686 & 1.99 & 1.87 & 1.15 & 1.47 & 2.16 \\
\hline TCOMP (\$MM) & 11681 & 15.64 & 74.55 & 0.00 & 4.03 & 15.55 \\
\hline ACOMP(\$MM) & 11681 & 4.70 & 6.29 & 1.2 & 2.5 & 5.3 \\
\hline TNV (\%) & 11024 & 2.99 & 17.04 & - & - & - \\
\hline ARET & 3504 & 0.24 & 6.82 & -2.77 & 0.14 & 3.24 \\
\hline ATTENDANCE & 11681 & 0.02 & 0.05 & 0.00 & 0.00 & 0.55 \\
\hline MVE (\$MM) & 11686 & 6655.37 & 15747.10 & 604.44 & 1619.06 & 5073.92 \\
\hline RND & 11686 & 0.08 & 2.28 & 0.00 & 0.00 & 0.03 \\
\hline LEV & 11686 & 0.57 & 0.24 & 0.42 & 0.58 & 0.72 \\
\hline FIRM_AGE & 11577 & 56.45 & 40.87 & 22 & 45 & 86 \\
\hline DIVERSIFY & 11671 & 0.89 & 0.32 & 1.00 & 1.00 & 1.00 \\
\hline CAPX & 10884 & 0.06 & 0.05 & 0.02 & 0.04 & 0.08 \\
\hline BETA & 11333 & 0.97 & 0.67 & 0.51 & 0.86 & 1.28 \\
\hline ROA & 11681 & 0.09 & 0.11 & 0.04 & 0.09 & 0.13 \\
\hline RET & 11525 & 0.16 & 0.56 & -0.14 & 0.11 & 0.36 \\
\hline STD_ROA & 11681 & 0.04 & 0.05 & 0.01 & 0.02 & 0.05 \\
\hline RET_VOL & 11175 & 0.42 & 0.19 & 0.28 & 0.37 & 0.51 \\
\hline DIR_HOLD (\%) & 11681 & 9.60 & 16.88 & 0.00 & 2.50 & 10.73 \\
\hline BD_SIZE & 11686 & 9.65 & 2.98 & 7 & 9 & 11 \\
\hline BD_INDP & 11686 & 0.64 & 0.18 & 0.53 & 0.67 & 0.78 \\
\hline OPTINT & 11669 & 0.35 & 0.29 & 0.04 & 0.34 & 0.58 \\
\hline INST_HOLD & 10617 & 60.42 & 19.00 & 47.84 & 62.07 & 74.56 \\
\hline G-INDEX & 9760 & 9.27 & 2.68 & 7 & 9 & 11 \\
\hline HI_PASTCEO_HOLD & 11681 & 0.04 & 0.19 & 0.00 & 0.00 & 0.00 \\
\hline DELAWARE & 11671 & 0.56 & 0.50 & 0.00 & 1.00 & 1.00 \\
\hline IND_DIR_BLK & 11424 & 0.03 & 0.17 & 0.00 & 0.00 & 0.00 \\
\hline MEDIA_MENTIONS & 11023 & 29.51 & 288.52 & 1.00 & 6.00 & 19.00 \\
\hline CENTRALITY & 10958 & 0.37 & 0.13 & 0.30 & 0.37 & 0.44 \\
\hline OUTSIDE_BD & 11490 & 0.87 & 1.17 & 0.00 & 0.00 & 1.00 \\
\hline CEO_OWN (\%) & 11189 & 2.57 & 6.29 & 0.09 & 0.32 & 1.45 \\
\hline TENURE & 10419 & 7.10 & 7.17 & 2.00 & 5.00 & 10.00 \\
\hline CEO_AGE & 11686 & 57.89 & 9.24 & 51.00 & 58.00 & 64.00 \\
\hline INSIDE_HIRE & 11120 & 0.69 & 0.46 & 0.00 & 1.00 & 1.00 \\
\hline
\end{tabular}


Panel B: Means of the variables by founder status

\begin{tabular}{|c|c|c|c|c|c|c|}
\hline Variable & $\begin{array}{l}\text { Non- } \\
\text { founder } \\
\text { firms }\end{array}$ & $\begin{array}{c}\text { Founder- } \\
\text { director } \\
\text { firms }\end{array}$ & $\begin{array}{l}\text { Founder- } \\
\text { CEO firms }\end{array}$ & $\begin{array}{l}\text { P-value of } \\
\text { diff. } \\
\text { between (1) } \\
\text { and (2) }\end{array}$ & $\begin{array}{l}\text { P-value of } \\
\text { diff. } \\
\text { between (1) } \\
\text { and (3) }\end{array}$ & $\begin{array}{l}\text { P-value of } \\
\text { diff. } \\
\text { between (2) } \\
\text { and (3) }\end{array}$ \\
\hline MTB & 1.83 & 2.61 & 2.38 & 0.00 & 0.00 & 0.14 \\
\hline TCOMP (\$MM) & 12.54 & 20.51 & 29.39 & 0.02 & 0.00 & 0.07 \\
\hline ACOMP (\$MM) & 4.66 & 4.77 & 4.89 & 0.76 & 0.65 & 0.79 \\
\hline TNV (\%) & 2.69 & 5.88 & 2.02 & 0.00 & 0.11 & 0.00 \\
\hline ARET & 0.12 & 0.19 & 0.81 & 0.01 & 0.01 & 0.07 \\
\hline ATTENDANCE & 0.02 & 0.02 & 0.02 & 0.28 & 0.86 & 0.20 \\
\hline MVE (\$MM) & 7059.81 & 6815.83 & 4107.15 & 0.84 & 0.00 & 0.03 \\
\hline RND & 0.04 & 0.11 & 0.29 & 0.00 & 0.21 & 0.36 \\
\hline LEV & 0.60 & 0.48 & 0.51 & 0.00 & 0.00 & 0.08 \\
\hline FIRM_AGE & 66.22 & 30.57 & 23.35 & 0.00 & 0.00 & 0.00 \\
\hline DIVERSIFY & 0.87 & 0.93 & 0.93 & 0.00 & 0.00 & 0.84 \\
\hline CAPX & 0.06 & 0.06 & 0.07 & 0.38 & 0.03 & 0.20 \\
\hline BETA & 0.88 & 1.23 & 1.24 & 0.00 & 0.00 & 0.92 \\
\hline ROA & 0.09 & 0.09 & 0.08 & 0.80 & 0.19 & 0.37 \\
\hline RET & 0.16 & 0.17 & 0.20 & 0.26 & 0.01 & 0.19 \\
\hline STD_ROA & 0.04 & 0.05 & 0.05 & 0.00 & 0.00 & 0.83 \\
\hline RET_VOL & 0.39 & 0.50 & 0.51 & 0.00 & 0.00 & 0.41 \\
\hline DIR_HOLD (\%) & 7.71 & 15.30 & 15.37 & 0.00 & 0.00 & 0.98 \\
\hline BD_SIZE & 9.88 & 8.82 & 8.22 & 0.00 & 0.00 & 0.00 \\
\hline BD_INDP & 0.67 & 0.53 & 0.58 & 0.00 & 0.00 & 0.00 \\
\hline OPTINT & 0.34 & 0.40 & 0.39 & 0.00 & 0.00 & 0.67 \\
\hline INST_HOLD & 60.44 & 58.95 & 61.74 & 0.18 & 0.25 & 0.04 \\
\hline G-INDEX & 9.56 & 8.61 & 8.10 & 0.00 & 0.00 & 0.01 \\
\hline HI_PASTCEO_HOLD & 0.03 & 0.12 & 0.01 & 0.00 & 0.00 & 0.00 \\
\hline DELAWARE & 0.54 & 0.59 & 0.62 & 0.14 & 0.02 & 0.50 \\
\hline IND_DIR_BLK & 0.03 & 0.03 & 0.02 & 0.86 & 0.07 & 0.16 \\
\hline MEDIA_MENTIONS & 22.99 & 52.50 & 46.61 & 0.21 & 0.42 & 0.56 \\
\hline CENTRALITY & 0.38 & 0.34 & 0.35 & 0.00 & 0.00 & 0.27 \\
\hline OUTSIDE_BD & 0.97 & 0.63 & 0.50 & 0.00 & 0.00 & 0.03 \\
\hline CEO_OWN (\%) & 1.79 & 2.79 & 6.95 & 0.00 & 0.00 & 0.00 \\
\hline TENURE & 5.98 & 6.57 & 14.53 & 0.25 & 0.00 & 0.00 \\
\hline CEO_AGE & 57.22 & 60.40 & 56.22 & 0.00 & 0.00 & 0.00 \\
\hline INSIDE_HIRE & 0.65 & 0.62 & 1.00 & 0.30 & 0.00 & 0.00 \\
\hline
\end{tabular}

This table presents summary statistics. Panel A presents the summary statistics for all firm-years. Panel B presents the variable means by the firm's founder status and p-values for differences in means between the various groups. All variables are as defined in the Appendix. P-values are based on standard errors clustered at the firm level. 
Table 2

Founder Directors and Firm Value

\begin{tabular}{|c|c|c|}
\hline VARIABLES & $\begin{array}{c}(1) \\
\text { Coefficient }\end{array}$ & $\begin{array}{c}(2) \\
\text { T-stat }\end{array}$ \\
\hline \multicolumn{3}{|l|}{ Founder variables } \\
\hline FDIR & $0.30 * * *$ & (3.34) \\
\hline FCEO & -0.04 & $(-0.37)$ \\
\hline PAST_CEO & 0.02 & $(0.56)$ \\
\hline FAM_CEO & $-0.40 * *$ & $(-2.53)$ \\
\hline \multicolumn{3}{|l|}{ Firm characteristics } \\
\hline LN(MVE) & $0.36 * * *$ & $(15.00)$ \\
\hline RND & $0.24 * *$ & $(2.23)$ \\
\hline LEV & $-0.40 * *$ & $(-2.15)$ \\
\hline FIRM_AGE & $-0.15 * * *$ & $(-4.08)$ \\
\hline DIVERSIFY & $0.13^{* *}$ & $(2.04)$ \\
\hline CAPX & $1.30 * *$ & $(2.46)$ \\
\hline BETA & -0.01 & $(-0.19)$ \\
\hline ROA & $5.69 * * *$ & $(9.75)$ \\
\hline RET & $0.63 * * *$ & (10.06) \\
\hline STD_ROA & $8.58 * * *$ & $(7.43)$ \\
\hline RET_VOL & 0.08 & $(0.34)$ \\
\hline DIR_HOLD & 0.00 & (1.19) \\
\hline Ln(BD_SIZE) & $-0.78 * * *$ & $(-6.47)$ \\
\hline BD_INDP & -0.02 & $(-0.11)$ \\
\hline OPTINT & $0.36 * * *$ & $(4.81)$ \\
\hline INST_HOLD & $-0.00 * * *$ & $(-3.06)$ \\
\hline G_INDEX & 0.00 & $(0.42)$ \\
\hline HI_PASTCEO_HOLD & -0.09 & $(-1.10)$ \\
\hline DELAWARE & $-0.14 * * *$ & $(-2.80)$ \\
\hline IND_DIR_BLK & 0.01 & $(0.10)$ \\
\hline \multicolumn{3}{|l|}{ CEO characteristics } \\
\hline MEDIA_MENTIONS & -0.00 & $(-1.45)$ \\
\hline CENTRALITY & $-0.71^{* * *}$ & $(-4.49)$ \\
\hline OUTSIDE_BD & -0.02 & $(-1.05)$ \\
\hline CEO_OWN̄ & 0.00 & $(0.78)$ \\
\hline TENÜRE & $0.01 * *$ & (2.28) \\
\hline CEO_AGE & $-0.01 * * *$ & $(-3.23)$ \\
\hline INSIDE_HIRE & -0.03 & $(-0.66)$ \\
\hline Observations & 6616 & \\
\hline R-squared & 0.576 & \\
\hline
\end{tabular}


This table presents the regression of Tobin's $Q$ on founder-director dummy and other variables. The dependent variable is Tobins' $Q(M T B)$, calculated as the market value of equity plus the book value of total liability divided by the book value of assets. The independent variables are as defined in the Appendix. The regression includes industry and year fixed effects. T-statistics are clustered at firm level. *, **, *** implies two sided significance at $10 \%, 5 \%$ and $1 \%$ respectively. 
Table 3

Founder Directors and CEO Pay for Performance Sensitivity

\begin{tabular}{|c|c|c|}
\hline VARIABLES & $\begin{array}{c}\text { (1) } \\
\text { Coefficient } \\
\end{array}$ & $\begin{array}{c}(2) \\
\text { T-stat }\end{array}$ \\
\hline \multicolumn{3}{|l|}{ Founder variables } \\
\hline DMKTVAL & $20.73 * * *$ & $(67.74)$ \\
\hline FDIR & 303.98* & $(1.76)$ \\
\hline FDIR * DMKTVAL & $2.24 * * *$ & $(50.13)$ \\
\hline FCEO & $588.65 * * *$ & $(2.94)$ \\
\hline FCEO * DMKTVAL & $3.47 * * *$ & (50.83) \\
\hline PAST_CEO & -38.89 & $(-0.29)$ \\
\hline PAST_CEO * DMKTVAL & $-0.20 * * *$ & $(-5.92)$ \\
\hline FAM_CEO & $-1,559.55^{* * *}$ & $(-3.37)$ \\
\hline FAM_CEO * DMKTVAL & $5.44^{* * *}$ & (24.92) \\
\hline \multicolumn{3}{|l|}{ Firm characteristics } \\
\hline Ln(MVE) & $1,434.71^{* * *}$ & (33.45) \\
\hline Ln(MVE) * DMKTVAL & $-1.01 * * *$ & $(-56.33)$ \\
\hline RND & 67.00 & $(0.79)$ \\
\hline RND * DMKTVAL & 0.12 & $(0.78)$ \\
\hline LEV & $458.79 *$ & $(1.71)$ \\
\hline LEV * DMKTVAL & $1.84^{* * *}$ & (23.19) \\
\hline Ln(FIRM_AGE) & -31.98 & $(-0.38)$ \\
\hline Ln(FIRM_AGE) * DMKTVAL & $-0.08 * * *$ & $(-3.42)$ \\
\hline DIVERSIFY & -154.79 & $(-0.76)$ \\
\hline DIVERSIFY * DMKTVAL & $-0.08 *$ & $(-1.84)$ \\
\hline CAPX & $-2,025.50$ & $(-1.63)$ \\
\hline CAPX * DMKTVAL & $-4.07 * * *$ & $(-12.11)$ \\
\hline BETA & -197.82 & $(-1.56)$ \\
\hline BETA * DMKTVAL & 0.05 & (1.60) \\
\hline ROA & $1,399.96 * *$ & (2.35) \\
\hline ROA * DMKTVAL & $1.43^{* * *}$ & (7.38) \\
\hline STD_ROA & $2,950.14 * *$ & $(2.01)$ \\
\hline STD_ROA * DMKTVAL & $-5.51 * * *$ & $(-10.39)$ \\
\hline RET_VOL & $2,231.84 * * *$ & $(4.08)$ \\
\hline RET_VOL * DMKTVAL & $5.53^{* * *}$ & (36.59) \\
\hline DIR_HOLD & 5.11 & $(1.29)$ \\
\hline DIR_HOLD * DMKTVAL & $0.01^{* * *}$ & $(7.74)$ \\
\hline Ln(BD_SIZE) & -256.20 & $(-1.06)$ \\
\hline Ln(BD_SIZE) * DMKTVAL & $-2.86 * * *$ & $(-42.64)$ \\
\hline BD_INDP & -174.19 & $(-0.51)$ \\
\hline BD_INDP * DMKTVAL & $-5.40 * * *$ & $(-63.16)$ \\
\hline INST_HOLD & -1.52 & $(-0.49)$ \\
\hline INST_HOLD * DMKTVAL & $0.02^{* * *}$ & $(15.72)$ \\
\hline
\end{tabular}




\begin{tabular}{lcc} 
G-INDEX & 14.34 & $(0.71)$ \\
G-INDEX * DMKTVAL & $0.13^{* * *}$ & $(23.45)$ \\
HI_PASTCEO_HOLD & -406.27 & $(-1.57)$ \\
HI_PASTCEO_HOLD * DMKTVAL & $0.12^{* * *}$ & $(19.79)$ \\
DELAWARE & 3.85 & $(0.04)$ \\
DELAWARE * DMKTVAL & $0.67 * * *$ & $(26.67)$ \\
IND_DIR_BLK & -67.67 & $(-0.24)$ \\
IND_DIR_BLK * DMKTVAL & $-0.99^{* * *}$ & $(-10.81)$ \\
& & \\
CEO characteristics & & \\
\hline MEDIA_MENTIONS & $21.99^{* * *}$ & $(155.37)$ \\
MEDIA_MENTIONS * DMKTVAL & $-0.00^{* * *}$ & $(-218.96)$ \\
CENTRALITY & $11,503.53^{* * *}$ & $(29.44)$ \\
CENTRALITY * DMKTVAL & $0.98^{* * *}$ & $(11.76)$ \\
OUTSIDE_BD & 14.47 & $(0.33)$ \\
OUTSIDE_BD * DMKTVAL & $-0.09^{* * *}$ & $(-10.70)$ \\
CEO_OWN & $489.50^{* * *}$ & $(44.55)$ \\
CEO_OWN * DMKTVAL & $4.07^{* * *}$ & $(1,042.90)$ \\
TENURE & -8.57 & $(-1.06)$ \\
TENURE * DMKTVAL & $0.38^{* * *}$ & $(170.40)$ \\
CEO_AGE & $-14.31^{* *}$ & $(-2.57)$ \\
CEO_AGE* DMKTVAL & $-0.01^{* * *}$ & $(-5.95)$ \\
INSIDE_HIRE & $-188.33^{*}$ & $(-1.66)$ \\
INSIDE_HIRE * DMKTVAL & $-1.75^{* * *}$ & $(-56.64)$ \\
& & \\
Observations & 6623 & \\
Pseudo-R2 & 0.4271 & \\
\hline
\end{tabular}

This table presents the median regression of CEO total compensation on change in shareholder wealth, founder-director dummy, and other variables. The dependent variable is TCOMP, as defined in Notes to Table 1. DMKTVAL is the change in the market value of equity over the year. All independent variables are as defined in the Appendix.

The regression includes 2-digit SIC industry and year fixed effects. T-statistics are clustered at firm level. The coefficients are 1000 times the regression coefficient. *, **, *** implies two sided significance at $10 \%, 5 \%$ and $1 \%$ respectively. 
Table 4

Founder Directors and Level of CEO Pay

\begin{tabular}{|c|c|c|}
\hline VARIABLES & $\begin{array}{c}(1) \\
\text { Coefficient }\end{array}$ & $\begin{array}{c}(2) \\
\text { T-stat }\end{array}$ \\
\hline \multicolumn{3}{|l|}{ Founder variables } \\
\hline FDIR & $-0.07 * * *$ & $(-2.98)$ \\
\hline FCEO & 0.01 & $(0.24)$ \\
\hline PAST_CEO & $-0.07 * * *$ & $(-3.80)$ \\
\hline FAM_CEO & $-0.16^{* * *}$ & $(-2.58)$ \\
\hline \multicolumn{3}{|l|}{ Firm characteristics } \\
\hline LN(MVE) & $0.38^{* * *}$ & (67.30) \\
\hline RND & 0.01 & $(1.38)$ \\
\hline LEV & $0.47^{* * *}$ & (13.53) \\
\hline FIRM_AGE & $0.02 * *$ & $(2.15)$ \\
\hline DIVERSIFY & -0.03 & $(-1.27)$ \\
\hline CAPX & $-0.65 * * *$ & $(-4.05)$ \\
\hline BETA & $-0.10 * * *$ & $(-6.09)$ \\
\hline ROA & 0.07 & $(0.88)$ \\
\hline RET & $-0.04 * * *$ & $(-2.89)$ \\
\hline STD_ROA & 0.01 & $(0.06)$ \\
\hline RET_VOL & $1.02^{* * *}$ & (14.27) \\
\hline DIR_HOLD & 0.00 & $(0.89)$ \\
\hline Ln(BD_SIZE) & $0.21^{* * *}$ & (6.79) \\
\hline BD_INDP & $-0.11 * *$ & $(-2.54)$ \\
\hline OPTINT & $0.90^{* * *}$ & (33.69) \\
\hline INST_HOLD & $0.00^{* * *}$ & $(6.41)$ \\
\hline G_INDEX & $0.01^{* * *}$ & $(4.01)$ \\
\hline HI_PASTCEO_HOLD & $-0.07 * *$ & $(-2.07)$ \\
\hline DELAWARE & $0.08^{* * *}$ & $(5.76)$ \\
\hline IND_DIR_BLK & -0.05 & $(-1.34)$ \\
\hline \multicolumn{3}{|l|}{ CEO characteristics } \\
\hline MEDIA_MENTIONS & 0.00 & $(0.48)$ \\
\hline CENTRALITY & $3.17^{* * *}$ & (58.98) \\
\hline OUTSIDE_BD & $0.01 * *$ & $(2.05)$ \\
\hline CEO_OWN & $-0.01 * * *$ & $(-5.38)$ \\
\hline TENÜRE & $0.00 * * *$ & $(4.05)$ \\
\hline CEO_AGE & -0.00 & $(-1.35)$ \\
\hline INSIDE_HIRE & $-0.08 * * *$ & $(-5.37)$ \\
\hline Observations & 6616 & \\
\hline R-squared & 0.784 & \\
\hline
\end{tabular}


This table presents the regression of CEO annual flow compensation on founder-director dummy and other variables. The dependent variable is $\log$ of ACOMP, calculated as the sum of (i) cash compensation (the sum of salary, bonus, and other annual cash payouts over the year); and (ii) the Black-Scholes value of options granted and the market value of restricted stock granted during the year and other long-term incentive payouts. The independent variables are as defined in the Appendix. The regression includes industry and year fixed effects. T-statistics are clustered at firm level. *, **, *** implies two sided significance at $10 \%, 5 \%$ and $1 \%$ respectively. 
Table 5

Founder Directors and CEO Turnover

\begin{tabular}{|c|c|c|}
\hline VARIABLES & $\begin{array}{c}\text { (1) } \\
\text { Marginal Effect }\end{array}$ & $\begin{array}{c}\text { (2) } \\
\text { Z-stat }\end{array}$ \\
\hline \multicolumn{3}{|l|}{ Founder variables } \\
\hline $\begin{array}{l}\text { RET } \\
\text { FDIR } \\
\text { FDIR * RET } \\
\text { FCEO } \\
\text { FCEO * RET } \\
\text { PAST_CEO } \\
\text { PAST_CEO * RET } \\
\text { FAM_CEO } \\
\text { FAM_CEO * RET }\end{array}$ & $\begin{array}{c}-0.011 \\
0.003 \\
-0.057 * * * \\
-0.008 * * \\
-0.005 \\
-0.001 \\
-0.001 \\
-0.009 \\
0.008\end{array}$ & $\begin{array}{l}(-0.44) \\
(0.98) \\
(-2.70) \\
(-2.24) \\
(-0.04) \\
(-0.33) \\
(-0.18) \\
(-0.41) \\
(0.27)\end{array}$ \\
\hline \multicolumn{3}{|l|}{ Firm characteristics } \\
\hline Ln(MVE) & $0.001^{*}$ & (1.71) \\
\hline $\mathrm{Ln}(\mathrm{MVE}) * \mathrm{RET}$ & -0.002 & $(-1.09)$ \\
\hline RND & -0.018 & $(-1.45)$ \\
\hline $\mathrm{RND} * \mathrm{RET}$ & -0.001 & $(-0.21)$ \\
\hline LEV & 0.001 & $(0.25)$ \\
\hline $\mathrm{LEV} * \mathrm{RET}$ & 0.001 & $(0.12)$ \\
\hline Ln(FIRM_AGE) & 0.002 & (1.16) \\
\hline Ln(FIRM_AGE) $*$ RET & 0.004 & (1.34) \\
\hline DIVERSIFY & 0.000 & $(0.06)$ \\
\hline DIVERSIFY * RET & -0.001 & $(-0.06)$ \\
\hline CAPX & 0.029 & $(1.24)$ \\
\hline $\mathrm{CAPX} * \mathrm{RET}$ & -0.011 & $(-0.31)$ \\
\hline BETA & -0.003 & $(-1.60)$ \\
\hline $\mathrm{BETA} * \mathrm{RET}$ & 0.001 & $(0.27)$ \\
\hline STD_ROA & $0.043 * *$ & $(2.06)$ \\
\hline STD_ROA * RET & $0.087 * *$ & (2.50) \\
\hline RET_VOL & $0.018 * *$ & (2.04) \\
\hline RET_VOL * RET & -0.015 & $(-1.04)$ \\
\hline DIR_HOLD & $0.000 *$ & $(-1.75)$ \\
\hline DIR_HOLD * RET & $-0.001 * * *$ & $(-3.19)$ \\
\hline BD_SIZE & 0.002 & $(0.51)$ \\
\hline BD_SIZE $*$ RET & 0.003 & $(0.47)$ \\
\hline BD_INDP & -0.004 & $(-0.60)$ \\
\hline BD_INDP * RET & $-0.029 * * *$ & $(-2.98)$ \\
\hline OPTINT & 0.001 & $(0.30)$ \\
\hline OPTINT * RET & $0.020 * * *$ & (2.73) \\
\hline INST_HOLD & 0.000 & $(-0.20)$ \\
\hline INST_HOLD * RET & 0.000 & $(-1.39)$ \\
\hline
\end{tabular}




\begin{tabular}{lcc} 
G_INDEX & 0.000 & $(0.32)$ \\
G_INDEX * RET & 0.001 & $(1.19)$ \\
HI_PASTCEO_HOLD & $0.017^{* *}$ & $(2.20)$ \\
HI_PAST_CEO_HOLD * RET & 0.000 & $(-0.04)$ \\
DELAWARE & 0.001 & $(0.25)$ \\
DELAWARE * RET & 0.004 & $(1.14)$ \\
IND_DIR_BLK & 0.005 & $(0.66)$ \\
IND_DIR_BLK * RET & 0.014 & $(1.20)$ \\
CEO characteristics & & \\
\hline MEDIA_MENTIONS & & \\
MEDIA_MENTIONS * RET & 0.000 & $(0.20)$ \\
CENTRALITY & 0.000 & $(-0.61)$ \\
CENTRALITY * RET & $-0.043^{* * *}$ & $(-5.43)$ \\
OUTSIDE_BD & $-0.044^{* * *}$ & $(-2.92)$ \\
OUTSIDE_BD * RET & -0.001 & $(-1.56)$ \\
CEO_OWN & -0.001 & $(-0.39)$ \\
CEO_OWN * RET & $-0.002^{* *}$ & $(-2.50)$ \\
TENURE & 0.001 & $(1.22)$ \\
TENURE * RET & 0.000 & $(0.22)$ \\
CEO_AGE & 0.000 & $(0.69)$ \\
CEO_AGE *RET & 0.000 & $(0.16)$ \\
INSIDE_HIRE & 0.000 & $(1.21)$ \\
INSIDE_HIRE * RET & 0.002 & $(0.81)$ \\
& 0.002 & $(0.62)$ \\
Observations & & \\
Pseudo-R2 & 5968 & \\
\hline
\end{tabular}

This table presents the logit regression of CEO turnover on founder-status and other explanatory variables. The dependent variable is $T N V$, as defined in Notes to Table 1. RET is the 2-digit SIC industry-adjusted returns measured cumulatively for the 12 month preceding the turnover event. $R O A$ is the return on assets the current year. ROA is the measured for the current year if the turnover occurs in the second six-month period of the fiscal year; it is calculated as the previous fiscal year ROA if the turnover happens in the first six-month period of the fiscal year following Parrino (1997).. All other variables are as defined in the Appendix. The regression includes 2digit SIC industry and year fixed effects. Robust Z-statistics in parentheses are clustered at firm level. *, **, *** implies two sided significance at $10 \%, 5 \%$ and $1 \%$ respectively. The marginal effect and standard errors of the marginal effect for the interaction terms FDIR*RET and FCEO*RET are computed using the method in Ai and Norton (2003) and Norton, Wang and Ai (2005). 
Table 6

Founder Directors and M\&A Announcement Returns

\begin{tabular}{|c|c|c|}
\hline VARIABLES & $\begin{array}{c}(1) \\
\text { Coefficient }\end{array}$ & $\begin{array}{c}(2) \\
\text { T-stat } \\
\end{array}$ \\
\hline \multicolumn{3}{|l|}{ Founder variables } \\
\hline FDIR & $1.29 * *$ & $(2.11)$ \\
\hline FCEO & $1.99 * * *$ & $(2.71)$ \\
\hline PAST_CEO & 0.30 & $(0.69)$ \\
\hline FAM_CEO & 2.13 & $(0.77)$ \\
\hline \multicolumn{3}{|c|}{ Transaction characteristics } \\
\hline PCT_CASH & $0.01 * * *$ & $(2.92)$ \\
\hline PCT_ACQ & 0.01 & $(0.27)$ \\
\hline DEĀL_SIZE & $-0.00 * * *$ & $(-3.26)$ \\
\hline DIV_MERGER & -0.19 & $(-0.59)$ \\
\hline REL_SIZE & $-2.62 * *$ & $(-2.41)$ \\
\hline \multicolumn{3}{|l|}{ Firm characteristics } \\
\hline LN(MVE) & $-0.32 * *$ & $(-2.37)$ \\
\hline RND & -3.64 & $(-1.49)$ \\
\hline LEV & 1.30 & $(1.25)$ \\
\hline FIRM_AGE & $0.77 * * *$ & $(2.74)$ \\
\hline DIVERSSIFY & 0.89 & (1.43) \\
\hline CAPX & -2.93 & $(-0.64)$ \\
\hline BETA & 0.43 & $(1.10)$ \\
\hline ROA & $3.83 *$ & $(1.74)$ \\
\hline RET & $1.08 * * *$ & $(2.78)$ \\
\hline STD_ROA & -12.04 & $(-1.58)$ \\
\hline RET_VOL & 1.88 & $(0.92)$ \\
\hline DIR_HOLD & -0.01 & $(-0.43)$ \\
\hline BD_SIZE & -0.60 & $(-0.76)$ \\
\hline BD_INDP & 1.24 & $(0.96)$ \\
\hline OPTINT & -0.01 & $(-0.01)$ \\
\hline INST_HOLD & -0.01 & $(-0.67)$ \\
\hline G_INDEX & -0.08 & $(-1.45)$ \\
\hline HI_PASTCEO_HOLD & -0.07 & $(-0.08)$ \\
\hline DELAWARE & 0.20 & $(0.60)$ \\
\hline IND_DIR_BLK & -0.92 & $(-1.26)$ \\
\hline \multicolumn{3}{|l|}{ CEO characteristics } \\
\hline MEDIA_MENTIONS & $0.00 * * *$ & $(4.25)$ \\
\hline CENTRALITY & -0.58 & $(-0.50)$ \\
\hline OUTSIDE_BD & 0.01 & $(0.05)$ \\
\hline CEO_OWN & 0.01 & $(0.19)$ \\
\hline
\end{tabular}




\begin{tabular}{lcc} 
TENURE & -0.01 & $(-0.43)$ \\
CEO_AGE & $-0.03^{*}$ & $(-1.74)$ \\
INSIDE_HIRE & 0.04 & $(0.09)$ \\
& & \\
Observations & 1734 & \\
R-squared & 0.110 & \\
\hline
\end{tabular}

The dependent variable is $A R E T$, the M\&A announcement returns in the $(-1,1)$ window around the announcement dates. All independent variables are as defined in the Appendix.

The regression includes 2-digit SIC industry and year fixed effects. T-statistics are clustered at firm level. *, **, *** implies two sided significance at $10 \%, 5 \%$ and $1 \%$ respectively. 
Table 7

Director Attendance at Board Meetings

\begin{tabular}{|c|c|c|}
\hline VARIABLES & $\begin{array}{c}\text { (1) } \\
\text { Coefficient }\end{array}$ & $\begin{array}{c}(2) \\
\text { T-stat } \\
\end{array}$ \\
\hline \multicolumn{3}{|l|}{ Founder variables } \\
\hline FDIR & $-0.02 * * *$ & $(-4.82)$ \\
\hline FCEO & 0.01 & $(1.51)$ \\
\hline PAST_CEO & -0.00 & $(-0.99)$ \\
\hline FAM_CEO & -0.01 & $(-1.21)$ \\
\hline \multicolumn{3}{|l|}{ Director characteristics } \\
\hline DIR_MTG_FEE & $-0.00 * *$ & $(-1.98)$ \\
\hline DIR_TENURE & -0.00 & $(-1.41)$ \\
\hline OTHERPOS & $0.01 * *$ & (2.13) \\
\hline DIR_COMP & 0.00 & $(1.00)$ \\
\hline RETIRED & 0.01 & $(1.06)$ \\
\hline STK_HOLD & 0.00 & $(0.13)$ \\
\hline DIR_AGE & $-0.00 *$ & $(-1.84)$ \\
\hline \multicolumn{3}{|l|}{ Firm characteristics } \\
\hline LN(MVE) & $-0.00 * * *$ & $(-3.38)$ \\
\hline RND & 0.00 & $(0.36)$ \\
\hline LEV & -0.00 & $(-0.36)$ \\
\hline FIRM_AGE & 0.00 & $(0.54)$ \\
\hline DIVERSIFY & $0.01 * *$ & (2.36) \\
\hline CAPX & -0.00 & $(-0.14)$ \\
\hline BETA & 0.00 & $(0.76)$ \\
\hline ROA & $0.03 *$ & $(1.84)$ \\
\hline RET & 0.00 & $(0.58)$ \\
\hline STD_ROA & 0.07 & (1.63) \\
\hline RET_VOL & -0.01 & $(-0.81)$ \\
\hline DIR_HOLD & 0.00 & $(0.17)$ \\
\hline BD_SIZE & $0.02^{* * *}$ & $(4.45)$ \\
\hline BD_INDP & -0.01 & $(-1.12)$ \\
\hline OPTINT & $0.01 * *$ & $(2.32)$ \\
\hline INST_HOLD & -0.00 & $(-0.86)$ \\
\hline G_INDEX & -0.00 & $(-1.36)$ \\
\hline HI_PASTCEO_HOLD & 0.00 & $(0.67)$ \\
\hline DELAWARE & -0.00 & $(-0.14)$ \\
\hline IND_DIR_BLK & 0.00 & $(0.14)$ \\
\hline \multicolumn{3}{|l|}{ CEO characteristics } \\
\hline MEDIA_MENTIONS & $0.00^{* * *}$ & $(2.73)$ \\
\hline CENTRALITY & -0.01 & $(-1.06)$ \\
\hline
\end{tabular}




\begin{tabular}{lcc} 
OUTSIDE_BD & 0.00 & $(0.18)$ \\
CEO_OWN & -0.00 & $(-1.63)$ \\
TENURE & 0.00 & $(0.18)$ \\
CEO_AGE & $0.00^{* * *}$ & $(2.80)$ \\
INSIDE_HIRE & $-0.00^{*}$ & $(-1.82)$ \\
& & \\
Observations & 3820 & \\
R-squared & 0.066 \\
\hline
\end{tabular}

This table shows the regression of director attendance on founder status and other explanatory variables. The dependent variable is Attendance (the average of the non-founder director's attendance problem in a firm. An individual directors attendance is coded as a dummy variable that equals 1 in a given fiscal year if a director missed more than $25 \%$ of the board meetings, and 0 otherwise). All independent variables are as defined in the Appendix.

The regression includes 2-digit SIC industry and year fixed effects. T-statistics are clustered at firm level. ${ }^{*}, * *, * * *$ implies two sided significance at $10 \%, 5 \%$ and $1 \%$ respectively. 